\title{
Monitoring Political Campaign In Social Media in Local Leaders Election of Tanjungpinang $2018^{\text {th }}$
}

\author{
Nur A Dwi Putri ${ }^{1}$, Nazaki $^{1}$ \\ \{na_dwiputri@yahoo.com ${ }^{1}$ \} \\ Universitas Maritim Raja Ali Haji, Indonesia ${ }^{1}$
}

\begin{abstract}
The simultaneous election momentum in Indonesia raises political euphoria in the community. With the development of technology and information also influence the political participation of the public in the momentum of the general election. One of the political participation of the community can be found on social media. The media has characteristics that people need to voice their wishes. Social media is a powerful weapon used by candidates to win elections. But it is unfortunate that activities on social media during the election take place not only containing positive content but also negative content that can harm candidates can even bring up conflicts that threaten public security and order. Panwaslu as an institution that has the authority has limitations in monitoring violations that occur on social media. Therefore, with a qualitative approach, this paper tries to trace the problems in supervising social media campaigns.
\end{abstract}

Keywords: Monitoring, political campaign, social media

\section{Introduction}

One measure of the realization of a good democracy is by measuring the political participation level, if the political participation level is high, it can make the implementation of democracy will be better and vice versa while lower political participation, the implementation of democracy can be said to be bad. As happened in Indonesia, the euphoria of society in welcoming the democratic party is very high. The high level of community participation is influenced by technological and information progress towards politics. Conventional political participation began to shift to modern political participation, namely the use of communication and information technologies such as Facebook, WhatsApp, Twitter and others. This is a new phenomenon that occurred in the development of Indonesian democracy. Conventional democracy gradually begins to transform into digital democracy.

This change occurs because social media can accommodate the things needed in political participation as explained by Disna Harvens in Andriadi [1] that there are five characteristics of social media, namely: participatory, openness, conversation, community and connectedness. These 
five characteristics are very relevant to democracy, therefore social media also has an important role in politics as a pillar of democracy that has the potential to increase social awareness [2].

The use of social media as a means of political participation provides its own effectiveness and efficiency which complements the methods of conventional political participation. The use of social media, on the one hand, can give a positive side to the other side also giving a negative effect. The negative effect of using social media is that it can give effect to the application of candidate socialization and campaign to voters. This negative impact can make voters easily influenced in determining their political choices. This phenomenon occurs a lot on social media accounts that are not registered with the supervisory agency spread hoax or fake news, spread speeches of hate that can trigger conflict in society. This is mostly done as one of the candidates' political marketing strategies to win the election.

The results of the Pol-Tracking Institute survey examined in May 2014 stated that more than 70 percent of the media were able to influence the political choices of the Indonesian people. The ordinary people consider the news in the media as a truth [3]. Therefore we must be concerned with new tools from this political participation. At the momentum of the elections, as we are now, political campaign activities carried out on social media cannot be ignored or put aside again.

Currently, 2018 is a political year, this year a democratic party is held in the form of regional head elections, one of which is in Tanjungpinang city. One that determines the number of votes obtained is during the campaign period. For Tanjungpinang, the community began to switch and enthusiastically campaigned through social media compared to conventional campaigns, plus campaigns by means of convoys were not allowed by the election commission.

One of the social media used by the people of Tanjungpinang City to the campaign is through Facebook. But what is quite interesting is that there is no special group created by the Tanjungpinang community itself or by the KPU as the media for both candidates to campaign. However, the people of Tanjungpinang agreed through the media that they determined that they would lead people who wanted to campaign in the Info Pinang group. There are two groups on Facebook that are quite a lot of members and are very active, namely Tanjungpinang Buy and Sell Exchange group totaling 189,188 members. In this buying and selling group, at the beginning of the campaign, many supporters or sympathizers started posting or uploading statuses, videos or photos of candidate pairs, but interestingly the people who joined the group together led investigators to upload campaign material to the Pinang info group it has already been formed so as not to interfere with special groups related to buying and selling.

Finally, by itself the implementation of digital democracy, in this case, the campaign took place in the Pinang info group which amounted to 44,162 members. Investigators began to whisper in the comments column in order to maintain their perspective image. But what happened after observing the campaign that occurred in the info pinang many people who became members in it uploaded status, pictures or videos containing hoax news and hate speech and contained elements of sara. Not only that, there are many comments that eventually lead to defamation of one of the partners or defamation of investigators.

From the observations that the authors did in Facebook Facebook Pinang group starting from February 1, 2018 to April 29, 2018 there were 34 Facebook accounts supporting Syahrul-Rahma couples who uploaded 129 upload statuses, and there were 33 Facebook accounts supporting Lis Maya couples uploading statuses. 134 uploads. Of the 263 uploads the authors considered that there were several uploads containing black campaigns, SARA, and false news. The many 
violations that continue to occur make the writer interested in knowing more about how to supervise the political campaign on social media in the Tanjungpinang regional head general election in 2018.

There have been several previous studies discussing social media and its relation to democracy such as the writings of Tia ZatuIkramina (2017), Airlangga University with the title "The Impact of the ITE Law in Digital Democracy: A Case Study of Digital Campaign in 2017 DKI Jakarta Regional Election" which found that State control in the form of regulations and legislation, namely the ITE and PKPU Laws on social media accounts are basically formed not to curb the autonomy of democracy itself, but rather to maintain the autonomy of democracy that goes beyond the limits and violates the rights of others [4].

Hendra Alfani [5] in his writings "The role of Facebook in the post-conflict local election political campaign in OgankemiringUlu district" which found that the role of Facebook for potential voters was as a means of finding information for supporters about candidates for regents and vice-regents and references to political views for supporters as well as a means of voicing aspirations, criticisms, suggestions and responses about information related to competing candidate pairs [6]. Not much different from Hendri, Budiyono (2016) in his article entitled "Social Media and Political Communication: social media as political communication ahead of DKI Jakarta Regional Election 2007" shows that Facebook can be used to convey the vision of candidates, and Khalayk can respond immediately both positive and negative. Negative responses appear in the form of harsh words and various sara. Therefore, a social media ethic needs to be established so that communication on social media is more polite [7]

Ratnia Solihah et al (2018) in her writing "The importance of overseeing participation in guarding democratic elections" examines the importance of participatory supervision in guarding the implementation of democratic elections. Election supervisory bodies such as the Election Supervisory Body (Bawaslu) at the Central Level, Election Supervisory Committee (Panwaslu) at the Regional Level, and the Election Administering Honor Council (DKPP) are not enough to realize democratic elections [8].

Of the four studies above, discussing how social media, especially Facebook, can encourage the development of democracy and the importance of monitoring activities on social media from elements of society. There has been no research that discusses how to supervise accounts on social media that violate rules, mechanisms and solutions to deal with black campaigns that are often spread on social media, so the authors are interested in discussing the monitoring of political campaigns on social media in an election.

\section{Method}

This study uses a qualitative descriptive research method. The writer uses descriptive qualitative so that the writer can explore research in-depth. In collecting data, researchers conducted direct interviews with informants who had been previously selected by researchers because researchers considered the chosen informants to be key informants who had the capacity to answer the questions that the authors proposed. The informants selected were the Chairperson of Tanjungpinang City Panwaslu, Chairperson of the Tanjungpinang Cybercrime Division, and the community of social media users. 
The main data in this study are data obtained through interviews with related informants. Data collection techniques are carried out by in-depth interviews (in-depth interview) which is supported by data collection with documentation studies by conducting a search and identification, to complement and sharpen the data from the interview results obtained.

\section{Result and Discussion}

\section{Rules regarding political campaigns on Social Media}

The stages of the campaign are one of the stages in the elections that tend to be more vulnerable when compared to other stages. This stage has a significant impact until after the election. At the campaign stage, threats can be in the form of friction between supporters, money politics (political money), incumbent political maneuvers, to black campaigns with issues of Tribe, Race, Religion, Inter-group (SARA) and hoaxes that are often distributed on social media.

According to Rogers and Storey in Dewanti [9], a campaign is a series of communication actions with the aim of creating certain effects on the community that is carried out on an ongoing basis over a period of time. Regarding the phenomenon of campaigns through social media, the KPU has further regulated KPU Regulation No.4 of 2017 article 47 concerning the Election Campaign for Governors and Deputy Governors, Regents and Deputy Regents, or mayors and deputy mayors. The arrangement was made with the intention that each candidate pair create an official account on social media for the purpose of the campaign, where the official account must be registered for later verification of ownership of the account [10].

In the regional head election in Tanjungpinang, the two candidate pairs have followed the rules conveyed by PKPU by submitting an official account to the KPU. The official account of the candidate pair is as follows:

Table .1 The name of the official account that has been registered in the Panwaslu of

$$
\text { Tanjungpinang }
$$

\begin{tabular}{ll}
\hline Lis Maya & Syahrul-Rahma \\
Media Sosial & Media Sosial \\
Facebook : TanjungpinangKampung & Instagram : SabarTanjungpinang \\
Kita & Facebook : - Sabar \\
Instagram : LIS-MAYA & $-\quad$ PerempuanSabar \\
Whatsapp : LIS-MAYA & - OrangnyaSabarTanjungpinang \\
& Fanpage : Orang Sabar \\
\hline
\end{tabular}

Source : Election Supervisory Committee of Tanjungpinang,2018

Furthermore, regarding campaign material on social media in accordance with KPU regulation No.4 of 2017 concerning Election Campaign, which is contained in article 48, it can be in the form of writing, sound, image, writing and pictures, sounds and images that are narrative, graphic, character, interactive or not. interactive, as well as those that can be received through the recipient of the message. According to Law No.10 of 2016 concerning Pilkada there are several restrictions on the election campaign. From these restrictions the author can take two restrictions which according to the author can be associated with campaigns on social media that is not insulting 
someone, religion, ethnicity, race, class, candidate pair of governor and deputy governor, candidate pair of regent and vice regent, candidate pair of mayor and vice mayor, and / or political party. Instigating, defaming, fighting political parties, individuals, and / or community groups. [11].

This is where the problem lies, the Election Commission and the election supervisory body do not have specific rules that discuss social media such as handling false news or hoaxes concerning election. Even though the fact in the fake news field is spread by irresponsible people on social media. Therefore, to deal with these false news, the election supervisory body must cooperate with the Police. This is done because the black campaign that occurs can only be snared by Law No. 19 of 2016 concerning Information and Electronic Transactions, namely Article 45 and 45 A concerning violating decency, gambling, insult / defamation, extortion and / or threats, spreading false news and misleading resulting in loss of consumers and spreading hatred or hostility of individuals and / or certain groups of people based on ethnicity, religion, race and class [12]. As for those who have the right to take action, the police, therefore, the Election Supervisory Body at the central level and the Election Supervisory Committee at the regional level work together to handle this black campaign by assisting GAKKUMDU integrated law enforcement centers. Gakkumdu was formed aimed at creating internal coordination and assistance.

\section{Monitoring mechanism for political campaigns on Social media}

Based on the joint regulation of the Republic of Indonesia general election watchdog, the Republic of Indonesia state police chief, and the Indonesian attorney general and the Indonesian attorney general number 14 of 2016, number 01 of 2016 and number 010 / JA / 11/2016 concerning integrated law enforcement centers on the election of governors and deputy governors, regents and deputy regents, as well as the mayors and deputy mayors, so the supervision of political campaigns that take place both in the social media and not carried out together. If there is a violation of a political campaign that has criminal elements, the election supervisor will hand over the handling of the case to the police. The number of violations that occur but are not reported is because there are still many people who do not know how the flow of reporting mechanisms and handling of campaign violations, the following the authors explain the flow of the mechanism as follows Figure 1.

With the existence of this integrated law enforcement center, the expectation that the violations that occurred during the campaign period can be resolutely resolved, but in reality on social media fake accounts remain with false issues uploaded by them. Of course this is something that must be explored. There are several challenges that must be faced with the existence of this concept, namely the challenge to build synergy between the parties involved, the common perception of the rule of law and each party must be able to build effective communication.

Based on the results of interviews with the Election Supervisory Committee of Tanjung Pinang City, the Election Supervisory Committee to date if it finds a violation on social media, the first conducted by the Election Supervisory Committee is to screen the shoot and then review whether it meets the elements that violate the law if the Election Supervisory Committee has determined that there is a violation the next step was to coordinate with the police to investigate further about 
the violations that occurred. In this step, usually the violations that occurred were not continued because there was insufficient evidence to be criminalized and ended peacefully.

Figure 1. The mechanism for handling alleged violations (findings)
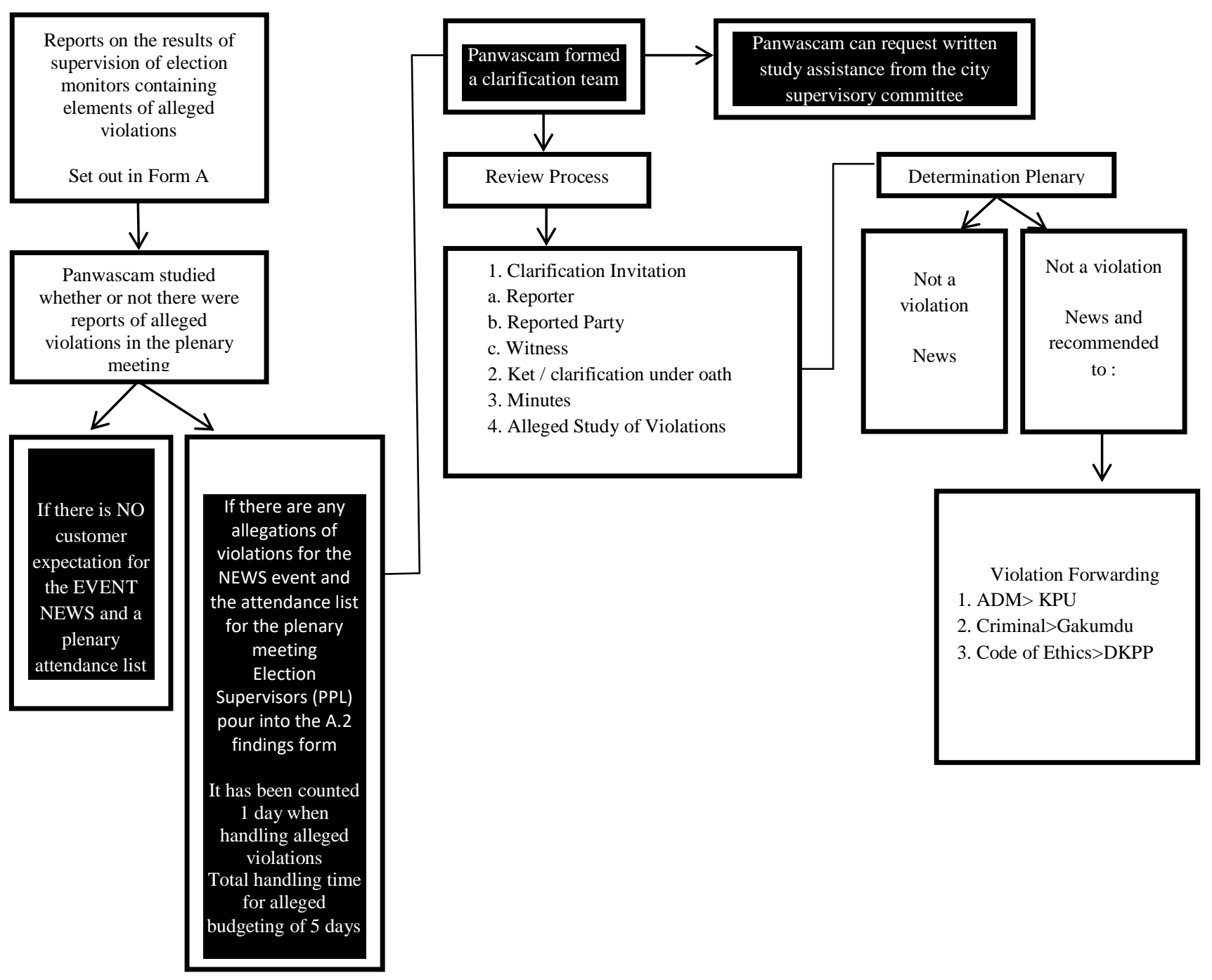
Based on the results of interviews with the police of Tanjung Pinang city resort, the police continue to monitor through the cyber crime division, then we will conduct a good investigation of the reports submitted by the Election Supervisory Committee and those we have found ourselves in the field, but the reports submitted by the Panwaslu are obstacles the report submitted is not enough evidence and the party reporting is not the party who feels aggrieved but the sympathizer or supporter of the candidate pair so that the report cannot be continued. The handling of reports in the cyber crime unit of the police is as follows figure 2

Figur 2. The flow of handling reports in cybercrime units

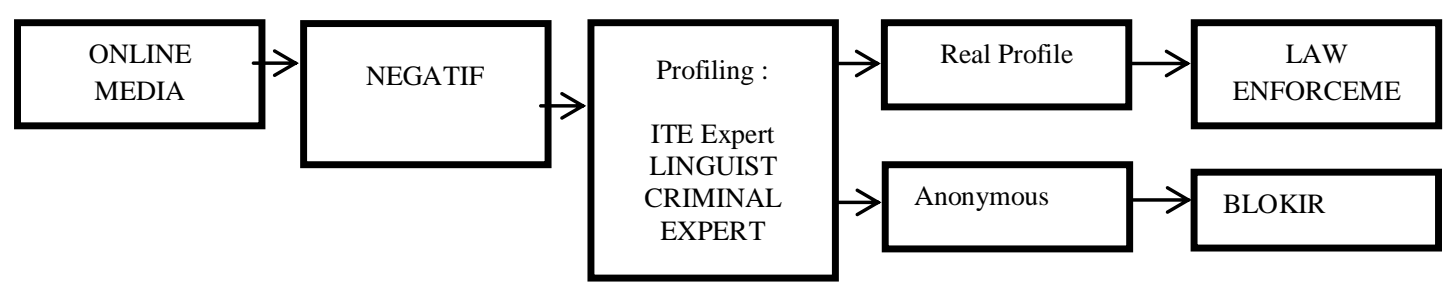

This is due to a lack of knowledge from the community about how the reporting mechanism of an offense. From the observation of the author in the infopinang facebook group, the authors found that there were several accounts that understood that the status uploaded by certain accounts was problematic but the actions taken only conveyed the violation through the Facebook police account, this matter according to the police could not be processed until reports that come directly and fill out the complaint form.

A community understanding of how to use social media well is very lacking. The results of the community service that the author did by inviting 100 participants consisting of youth members, community empowerment institutions and students found that many of them did not understand the reporting mechanism and how about the status and comments that have fake content. When the author confirmed to the Election Supervisory Committee and the District Police confirmed that socialization to the community had not been done much. Socialization efforts to date have been carried out only through banners and posters.

\section{Conclusion}

Monitoring of political campaigns on social media must be done by collaborating with the police and prosecutors to run optimally. This is done because determining a violation that has a criminal element is not the domain of the election supervisory committee. Election supervisory committees can only supervise official accounts when candidates outside the official account cannot be handled by the KPU. The violations that occur on social media at the time of voting to the Tanjungpinang City area are mostly carried out by the supporting accounts of the candidate pairs who are not registered with the KPU. The synergy of the three that is manifested in an integrated law enforcement center must be carried out effectively and efficiently, especially with 
regard to equality. perception of the applicable legal rules. The violations that continue to occur on social media are caused by the lack of public knowledge on how to use social media that does not violate the law so that there are still many people who easily spread fake content that can harm the candidate pairs and reporting mechanisms for violations that occurred where this caused a high number of violations but low reporting figures.

The suggestions that the writer can convey on this occasion are Bawaslu must have its own rules governing campaigns that occur on social media considering that social media is currently the cheapest political campaign tool and is widely used by candidates participating in an election and Socialization of good campaigning activities on social media must be encouraged.

\section{References}

[1] F. Andriadi, Demokrasi di Tangan Netizen Tantangan dan Prospek Demokrasi Digital. Jakarta: RMBooks, 2016.

[2] A. Fayakhun, Demokrasi Di Tangan Netizen (Tantangan dan prospek demokrasi Digital). Jakarta: RM.Books, 2016.

[3] R. Zaman, Perjalanan Panjang Pilkada Serentak. Jakarta: expose, 2016.

[4] T. Z. Ikramia, "Dampak UU ITE dalam Demokrasi Digital: Studi Kasus Kampanye Digital dalam Pilkada DKI Jakarta Tahun 2017," 2017.

[5] H. Alfani, "Peran Facebook dalam Kampanye Politik Pemilukada di Kabupaten Ogan Kemiring Ulu," LUGAS J. Komun., vol. 2, no. 1, pp. 42-50, 2018.

[6] H. Alfani, "Peran Facebook dalam kampanye politik pemilukada di kabupaten ogan kemiringulu," JurnalLugas, vol. 2, no. 1, 2018.

[7] Budiyono, "Media Sosial dan Komunikasi Politik: Media Sosial sebagai Komunikasi Politik menjelang Pilkada DKI Jakarta 2017," J. Komun., vol. 11, no. 1, 2016.

[8] R. Solihah, A. Bainus, and I. Rosyidin, "Pentingnya Pengawasan Partisipatif dalam mengawal pemilihan umum yang demokratis," J. Wacana Polit., vol. 3, no. 1, 2018.

[9] S. C. Dewanti, "Penyalahgunaan Media Sosial dan antisipasinya pada kampanye pilkada serentak 2018. INFO singkat. Vol X,No.04/II/Puslit/Februari/2018,” 2018.

[10] KPU, "Peraturan KPU No.4 Tahun 2017 Tentang Kampanye Pilkada."

[11] UUD, "Undang-Undang No.10 Tahun 2016 Tentang PILKADA." 2016.

[12] UUD, "UU Nomor 19 Tahun 2016 Tentang Informasi dan Transaksi Elektronik.". 